\title{
DESIGN AN AUTOMATIC MAXIMUM POWER POINT TRACKER (MPPT) COUPLED WITH SOLAR CELLS ARRAY Eskander S. $\mathrm{S}^{1}$. and Nour H. $\mathbf{M}^{2}$. 1 Electric Power Eng. Dept., Fact. of Eng. Mansoura Univ \\ 2 Energy and Power Dept., Agric. Eng. Res. Inst., ARC. Dokki, Giza .
}

\begin{abstract}
The aim of this paper is the design of an automatic voltage regulator device for regulating the load voltage supplied by solar cells array (SCA). The device contains DC control circuit (DCCC) and automatic voltage regulating circuit. This circuit senses any deviation of load voltage from that at maximum power point (MPP) of SCA. As the voltage deviated away from the voltage at MPP, the circuit changes its state. Then, the operation of the circuit at this instant changes the performance of DCCC triggering circuit. Consequently, the (DCCC) will return back the load voltage deviated to that equal to the voltage at MPP. Through this paper the proposed construction of the automatic control voltage device is illustrated. Its design procedures as will as its performance are investigated. The proper operation of the proposed regulator shows that it's very suitable for coupling with photovoltaic power systems and agricultural loads (DC Irrigation pump).

In the present paper, a novel circuit, referred to as the generation control circuit (GCC), which enables maximum power to be obtained from all of the PV modules even if some of the modules are prevented from receiving light. The proposed circuit enables the individual PV modules to operate effectively at the maximum power point tracking, irrespective of the series connected PV module system. In addition, the total generated power is shown experimentally to increase for the experimental set-up used in the present study.
\end{abstract}

Keywords: MPPT, photovoltaic systems, PV controller, curve fitting, pump.

\section{INTRODUCTION}

Solar power is a renewable source of energy, which has become increasingly popular in modern times. It has obvious advantages over nonrenewable energy sources, such as coal, oil and nuclear energy. It is nonpolluting, reliable and can produce energy anywhere that there is sun shining, so its resources are not going to run out anytime. It even has advantages over other renewable energy sources, including wind and water power. Solar power is generated using solar panels, which do not require any major mechanical parts, such as wind turbines. These mechanical parts can break down and cause maintenance issues and can also be quite noisy. Both of these issues are virtually non-existent with solar panels. Also, the solar cells, that connected together make up the solar panel, can last up to several decades without replacement. [Yang,et al, 2012].

The advantages of solar energy are: 1) abundant; 2) pollution free; 3) distributed throughout the earth; and 4) recyclable.. With the development of technologies, the cost of the photovoltaic or solar array is awaited to reduce continuously in the future, making them useful for agricultural and industrial applications [Rahmam,S,2008]. 
Photovoltaic (PV) is a method of generating electrical power by converting solar radiation into direct current electricity using semiconductors that exhibit the photovoltaic effect. Photovoltaic power generation employs solar panels comprising a number of cells containing a photovoltaic material. Materials presently used for photovoltaic include mono crystalline silicon, polycrystalline silicon, amorphous silicon, cadmium telluride, and copper indium selenide /sulfide. Due to the growing demand for renewable energy sources, the manufacturing of solar cells and photovoltaic arrays has advanced considerably in recent year [Eskander S. S 2011].

However, there is a drawback to solar power energy can only be produce when the sun is shining. To overcome this, usually solar panels are coupled with back up rechargeable batteries, which can store excess power generated during the day and use it to provide energy to systems when there is no sun shining. In this way solar power can be used to power houses and other large scale systems. In these systems dc to ac conversion is needed. This is because the solar panel produces an output that is dc (direct current) and the power supply in homes usually runs on ac (alternating current), so conversion is required. For this project, the load to be connected only requires dc input, so dc to ac conversion is not needed. Instead, dc to dc conversion would be used to provide the correct power to the system from the power generated by the solar panel. Using this information, a number of design solutions were determined and considered

The installation of photovoltaic (PV) generation systems is rapidly growing in response to concerns related to energy security and environmental issues such as global warming. PV generation system is considered as a clean and environmentally-friendly source of energy and it is operated either in standalone or grid connected modes. The standalone PV generation system is attractive as an indispensable electricity source for remote areas. However, PV generation systems have two major problems which are related to low conversion efficiency of about 9 to $12 \%$ especially in low irradiation conditions and that the amount of electric power generated by PV arrays varies continuously with weather conditions. Therefore, considerable research is being carried out to increase the efficiency of PV systems by operating the system at maximum output power for any temperature and solar radiation level. [ Patil, and Mahadik 2012]

In designing photovoltatic (PV) generators, the obtaining of the maximum amount of solar energy converted to meet the load requirements is required for the economic purpose. For achieving the aim of extracting maximum power from the PV generator, the design of maximum power tracking system must be designed. Most maximum power point trackers (MPPT) use some form of power electronic variable such as DC to DC transformer. The simplest type of MPPT is the array reconfiguration controller [Salmah. Z.eta/1998]. Other type of MPPT uses a pilot cell as a voltage reference and operates the array at fixed maximum power point voltage as in [Schaefer J.F.2005]. A design of a simple, inexpensive, and efficient maximum power tracker is presented in [Ziad M.Salameh,2010]. The photovoltaic system, it is required to use maximum power point tracking (MPPT) control scheme to track the maximum output power operating point 
irrespective of operating conditions of insolations and temperature of the PV array.[Tse, K. K.2012].

In this paper proposed construction of the automatic maximum power point tracker (MPPT) circuits coupled with solar cells array was designed procedures as well as its performance is investigated during operating DC irrigation pump.

\section{MATERIALS AND METHODS}

\section{Photovoltaic cell :}

\section{Characteristics Of the Photovoltaic(V- I).}

Photovoltaic (PV) offers an environmentally friendly source of electricity, of which the fuel is sunshine, a renewable energy. Today, this way of electricity generation, however, has been relatively costly very often, the success of a PV application depends on whether the power electronics device can extract sufficiently high power from the PV arrays to keep overall output power per unit cost low. The maximum power point tracking (MPPT) of the PV output for all sunshine conditions, therefore, becomes a key control in the device operation for successful PV applications. The MPPT control is, in general, challenging, because the sunshine condition that determines the amount of sun energy into the PV array may change all the time, and the current voltage characteristic of $\mathrm{PV}$ arrays is highly nonlinear. The Photovoltaic which used was mono-crystalline PV, Germany made. The photo of the PV is shown in figure (1), and the specifications of the photovoltaic module is shown in table, (1).

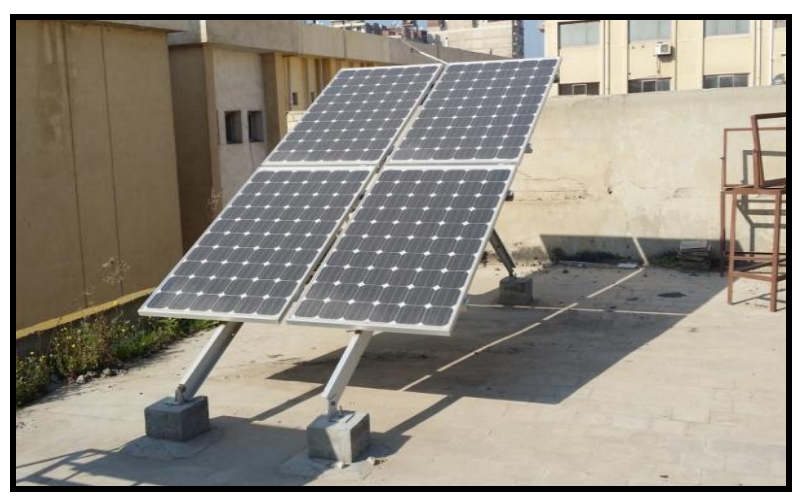

Fig.(1) : The photo of the solar cells modules. 
Table (1): The specifications of the photovoltaic module.

\begin{tabular}{|l|c|}
\hline Cell Technology & Specifications \\
\hline Panel dimensions (m x m) & $1.52 \times 1.02$ \\
Front cover (glass),mm & 6 \\
Cell dimensions (mm) & $120 \times 120$ \\
Maximum Power (Watt) & 240 \\
Open circuit voltage ,(V) & 37.4 \\
Short circuit current ,(A) & 8.6 \\
Cell Area (m²) & 0.014 \\
Aperture Area (m²) & 0.64 \\
Size of cells (wide and high) & $156 \mathrm{~mm}^{2} \times 156 \mathrm{~mm}$ \\
\hline
\end{tabular}

\section{Centrifugal Water Pump:}

A solar-powered water pump uses the sun's energy to pump water and can be an excellent choice in applications where the volume of water to be pumped is relatively small, the hours of operation limited, the sunshine is plentiful, and access to electricity is a challenge. This form of sump pump is frequently used with water features such as birdbaths, fountains, and small ponds. Cisterns and water tanks that only need occasional pumping are also good candidates for a solar-powered water pump.

This type of pump typically operates on 12 volts direct current (DC motor). A solar panel converts solar energy to DC electricity that energizes the pump, meaning that it will only operate when sunshine is available. As there is no storage battery involved, it is considered to be low-maintenance.

A solar-powered water pump will typically operate four to six hours per day on full sunshine. On overcast or intermittently cloudy days, the pump will operate for less time. DC-powered pumps designed for solar operation are highly efficient.

The pump which used is Brazilian made, the photo of the DC pump is shown in figure (2) and also the specifications of the pump illustrated in table (2).

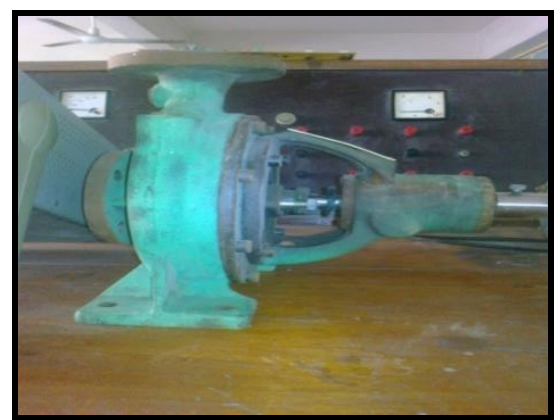

Figure (2): The photo of the water pump 
Table (2): The specifications of the (DC) pump :

\begin{tabular}{|l|c|}
\hline Characteristics & Specifications \\
\hline DCV & $6-80$ \\
H max,$(\mathrm{m})$ & 3 \\
Flow rate, $(\mathrm{Q}),(\mathrm{L} / \mathrm{h})$ & $0.10-10.000$ \\
Pump, $(\mathrm{W})$ & $0.5-60$ \\
Duty work & The pump can sustain heavy duty work for a \\
& day. \\
\hline
\end{tabular}

The pump used was connected with DC motor which operated by photovoltaic power system as shown in fig (3) ,while the Experimental arrangement for measurement of MPPT device and pump connected with DC Motor with automatic maximum power point tracker (MPPT) circuits during the laboratory experiments is shown in fig (4). The discharge of the pump was measured according to the revolutions of the pump and that is affected by the solar radiation. And which is registered with the time. The consumed energy to operate the pump is recorded, and the design maximum power point tracker (MPPT) also has been tested over time measurements.

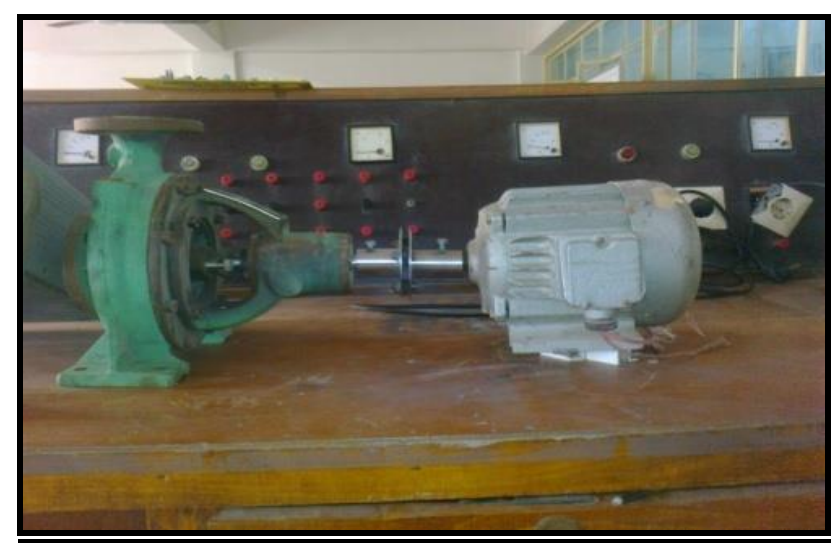

Figure (3) : The photo of the pump connected with (DC) motor. 


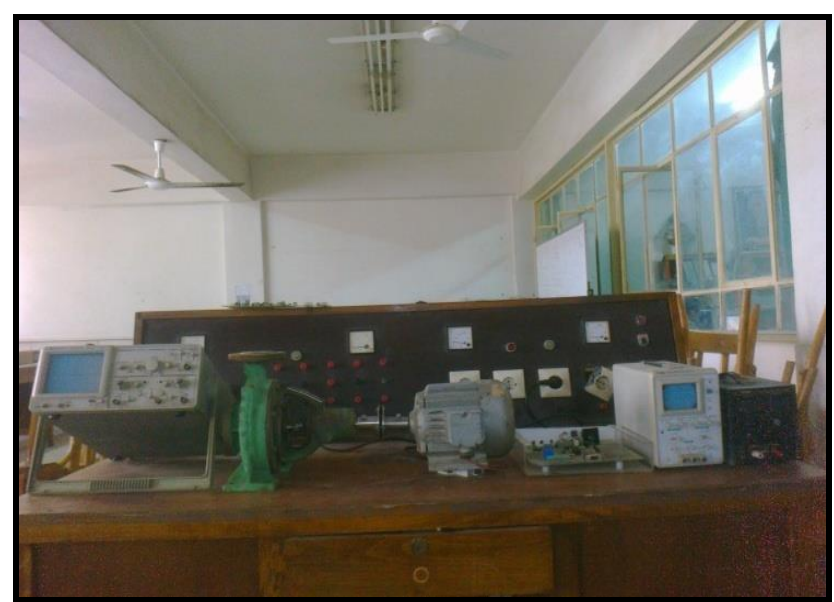

Figure (4) : Experimental arrangement for measurement of MPPT device and pump connected with DC Motor

\section{ELECTRONIC AND AUTOMATIC CONTROL CIRCUITS: Verbal Specifications of Automatic Control Circuit :}

The control circuit under design operates with the (DCCC).The (DCCC) is designed for chopping the (SCA) output voltage. The triggering frequency of the (DCCC) is adjusted for obtaining the voltage at maximum power point of (SCA) for any selected load (it calls as the optimum frequency). The automatic control circuit under design must sense the voltage at (MPP). Any increasing of $\mathrm{V}_{\mathrm{mp}}$ means that the load on (SCA) increases and the (SCA) terminal voltage becomes $\left(V_{\mathrm{Ln} n}\right.$ ) as shown in Fig.1. At this circumstance, the electronic control circuit operates automatically and adjusts the triggering frequency of the (DCCC). The adjusted frequency is less than the optimum one because $\left(\mathrm{V}_{\mathrm{Ln})}\right.$ has a large value than $\left(\mathrm{V}_{\mathrm{mp}}\right.$. Consequently, the load voltage returns back to the voltage at maximum power point.

\section{Electronic Circuit of the Automatic Voltage Regulator:}

To achieve the previous specifications of the voltage regulator, Schmitt circuit is designed in conjunction with a normally on transistor circuit. The regulator has two stages of operation. In the first stage Schmitt circuit senses the load voltage $\left(\mathrm{V}_{\mathrm{mp}}\right)$. At this moment it supplies a positive voltage to the base of the (npn) transistor. So, the transistor is in on condition and the (DCCC) frequency is the optimum one. At the second stage, the load increases and diverts away from the optimum condition. At this instant Schmitt circuit changes its output voltage level to the negative one. Hence, the (npn) transistor goes to the(OFF) condition. Consequentially, the DCCC frequency is changed for maintaining the (SCA) output voltage precisely at $\left(\mathrm{V}_{\mathrm{mp}) \text {. }}\right.$

Design of npn Transistor Circuit:

Fig.(5) shows the NPN transistor circuit connected with the triggering circuit of the a stable multi-vibrator of DCCC. Now suppose that a positive voltage comes from Schmitt output to the base of the transistor. Hence, npn 
transistor becomes on and its collector resistance is paralleled with $R_{5}$ for giving the optimum frequency, $1000 \mathrm{~Hz}$. The values of $\mathrm{R}_{4}$, adjustable resistance $R_{5}$ and $C_{1}$ are designed for operating the DCCC at variable frequency levels.

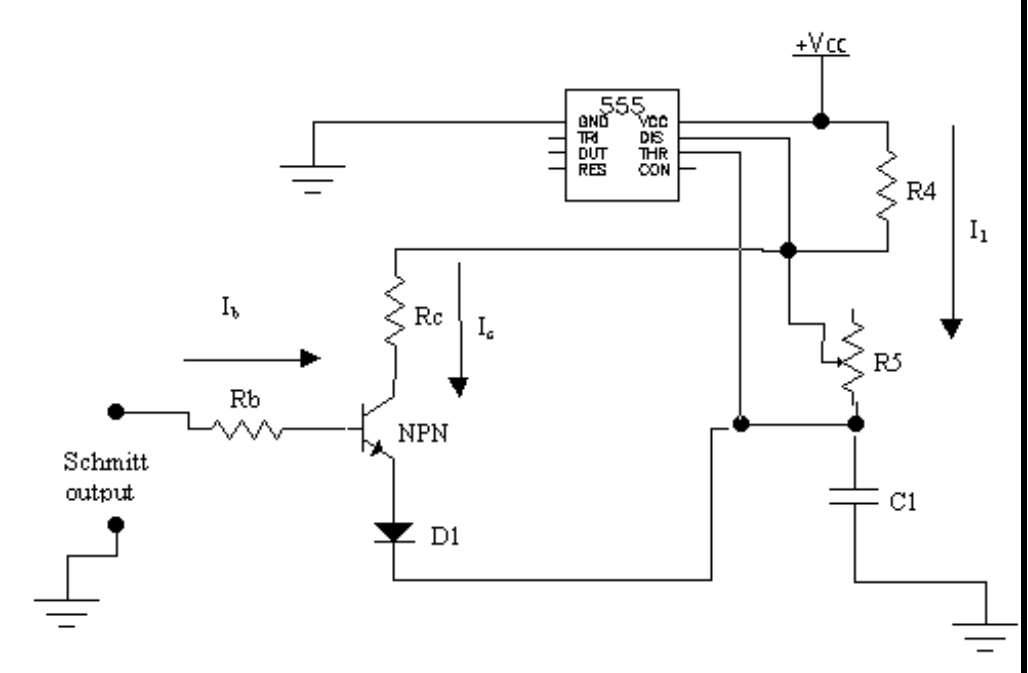

Fig.5 : The Proposed Connection of the Transistor Circuit with (IC555) a stable Multi-vibrator.

Design Values of $\mathbf{R}_{5}$ and $\mathbf{R}_{\mathrm{c}}$ :

As $n p n$ transistor switches on $R_{5}$ is connected in parallel with $R_{c}$ for giving the optimum frequency, $1000 \mathrm{~Hz}$. So,

$$
\begin{aligned}
& \mathrm{f}=\frac{1.44}{\mathrm{C} *\left(\mathrm{R}_{4}+2 * \mathrm{R}_{5} \backslash \backslash \mathrm{R}_{\mathrm{c}}\right)}[\mathrm{Hz}] \\
& 1000=\frac{1.44}{0.1 \mathrm{uf} *\left(1 \mathrm{k}+2 * \mathrm{R}_{5} \backslash \backslash \mathrm{R}_{\mathrm{c}}\right)}
\end{aligned}
$$

So,

$R_{5} \| R_{c}=6.7 \mathrm{k} \Omega$

As the Schmitt output goes to the negative level, the transistor is switched off. Thus, the frequency must be adjusted to $900 \mathrm{~Hz}$. Hence;

$900=\frac{1.44}{0.1 \mathrm{uf}\left(1 \mathrm{k} \Omega+2 * \mathrm{R}_{5}\right)}$

Thus;

$R_{5}=7.5 \mathrm{~K} \Omega$ and $R_{c}=62 \mathrm{~K} \Omega$ 


\section{Design Value of $\mathbf{R}_{\mathrm{b}}$}

As the transistor is in the on state, the collector current reaches to the saturation value, $I_{\text {Csat }}$, which is given by,

$\mathrm{I}_{\text {Csat }}=\frac{\mathrm{V}_{\mathrm{cc}}-\mathrm{I}_{1} * \mathrm{R}_{1}-\mathrm{V}_{\text {CEsat }}-\mathrm{V}_{\mathrm{DF}}-(1 / 3) * \mathrm{~V}_{\mathrm{cc}}}{\mathrm{R}_{\mathrm{c}}}$

Where;

$\mathrm{V}_{\mathrm{cc}}$ : is the biasing supply voltage,

$I_{1}$ : is the maximum current provided to the astable multi-vibrator circuit which is equal to $100 \mathrm{~mA}$,

$\mathrm{V}_{\text {CEsat }}$ is the collector emitter voltage equal to $0.2 \mathrm{~V},(1 / 3)$

${ }^{*} V_{c c}:$ is represents the lower level of capacitor voltage and

$V_{D F}$ : is the diode forward voltage, which is equal to $0.7 \mathrm{~V}$.

The typical values of $\mathrm{I}_{\mathrm{Csat}}$ and $\mathrm{h}_{\mathrm{FEmin}}$ as obtained from the transistor data sheet are $0.13 \mathrm{~mA}$ and 41 .

$$
\mathrm{I}_{\mathrm{Bmin}}=\frac{\mathrm{I}_{\text {Csat }}}{\mathrm{h}_{\text {FEmin }}}
$$

$I_{\mathrm{Bmin}}=3.2 \mathrm{uA}$

Hence,

$$
\mathrm{R}_{\mathrm{B}}=\frac{\text { schmitt output voltage }-\mathrm{V}_{\mathrm{BEon}}-\mathrm{V}_{\mathrm{DF}}-(1 / 3) * \mathrm{~V}_{\mathrm{cc}}}{\mathrm{I}_{\mathrm{Bmin}}}
$$

Where,

$$
\mathrm{V}_{\mathrm{BEon}}=0.7 \mathrm{~V} \text {. }
$$

Hence,

$$
R_{B}=2.6 \mathrm{M} \Omega
$$

\section{Schmitt Circuit Design :}

Figure (6) illustrates the designed inverting Schmitt circuit, which composed of IC741, diode and two resistors $R_{3}, R_{4}$. The design of Schmitt circuit requires only the upper trigger (UTP) and lower trigger (LTP) points. For our purpose the lower trigger point is chosen as zero. So, using of the diode achieves this purpose. On the other hand the selection of the UTP depends upon the optimum operating point of the arbitrary load selected. Through the design, the Schmitt UTP is selected larger than the voltage at maximum power point $V_{m p}$. The value of $V_{m p}$ for tested SCA is $13.5 \mathrm{~V}$. hence, the UTP of Schmitt circuit is chosen as $14.5 \mathrm{~V}$. As the load voltage equal to $V_{m p}$ (optimum operating voltage), Schmitt output saturates to the positive level of $+\left(\mathrm{V}_{\mathrm{cc}}-1\right)$. 


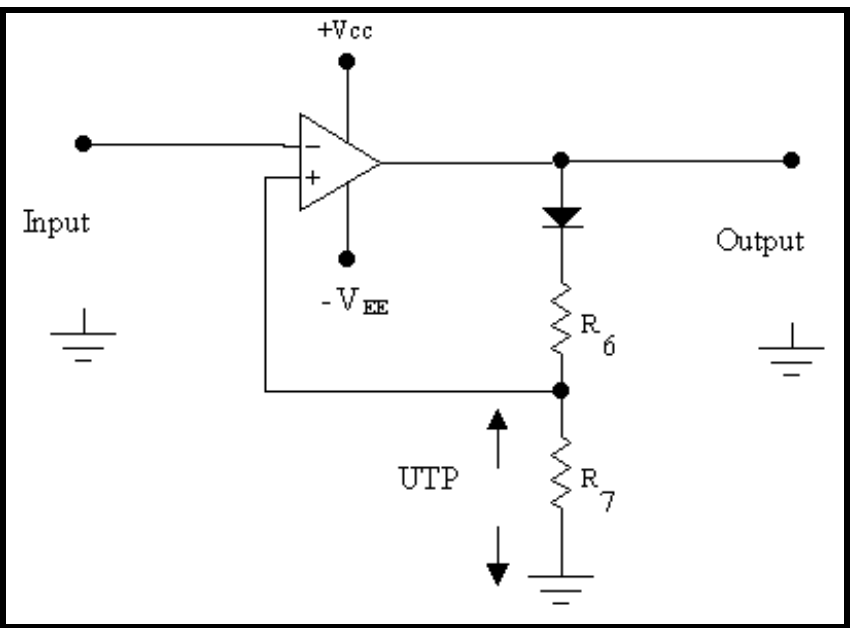

Fig.6 : Inverting Schmitt Circuit with (LTP) Close to Zero

Schematic Diagram and Operation of the Regulator Elements :

Figure (7) shows the complete circuit diagram of the automatic voltage regulator. The figure contains all circuit designed. It has input from SCA connected with an inverter, bridge, (DCC) and the load. Furthermore, it has the automatic control circuit and the (npn) transistor. The figure also contains the trigger circuits, which are designed suitable for operating all thrusters of the inverter and DCC. The electrical performance of the inverter operates as an element of the automatic voltage regulator is recorded by the oscilloscope.

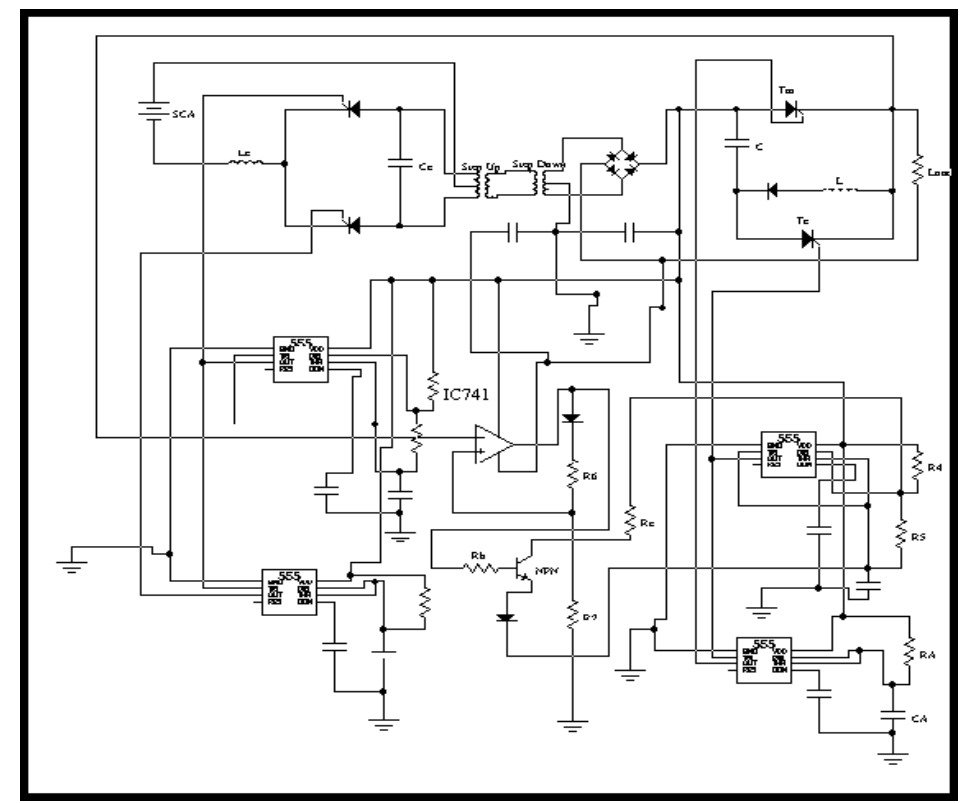

Fig.7 : Schematic Diagram of the Proposed Voltage Regulator. 


\section{Control Circuit Design Procedures:}

Fig.8 illustrates the experimental characteristics of SCA with and without using DCCC. The upper curve is the SCA characteristic without using DCCC, where the second one represents the SCA behavior at the instant of using DCCC with chopping frequency $1000 \mathrm{~Hz}$. The Figure shows that the two characteristics correspond to each other. An arbitrary load $\left(L_{n}\right)$ is selected as shown in Figure 1. The triggering frequency requires for adjusting the load voltage $\left(\mathrm{VL}_{\mathrm{n}}\right)$ to $\left(\mathrm{V}_{\mathrm{mp}}\right)$ is calculated from the following formula

$f=1774.93-817.378 L_{R}+112.835 L_{R}^{2}[\mathrm{~Hz}]$

Where,

$L_{R}$ is load ratio $=\frac{L_{n}}{L_{o}} \quad, L_{n}$ and $L_{o}$, is in Ohm

The formula is build up experimentally as in reference [4].So, the required frequency for adjusting the load voltage is $f=900 \mathrm{~Hz}$

Hence;

Optimum frequency $=1000 \mathrm{~Hz}$

Adjusted frequency $=900 \mathrm{~Hz}$

Characteristics of Solar Cells Array:

Also, figure (8) illustrates the ( I-V) characteristics of solar cells array under test at selected insulation level, $500 \mathrm{w} / \mathrm{m}^{2}$. $\mathrm{L}_{0}$ represents the load at maximum power point called the optimum load at which the SCA should be loaded. $\left(L_{n}\right)$ represents an arbitrary load further than the optimum one. The $(\mathrm{SCA})$ terminal voltage corresponding to $\left(\mathrm{L}_{0}\right)$ is $\left(\mathrm{V}_{\mathrm{mp}}\right)$, where $\left(\mathrm{V}_{\mathrm{Ln}}\right)$ represents the (SCA) terminal voltage related to the load $\left(L_{n}\right)$. The figure shows that $\left(V_{L n}\right.$ )is diverted away from $\left(V_{\mathrm{mp}}\right)$. The proposed automatic controller provides electronic control of load voltage leading to fix it at the voltage at maximum power point.

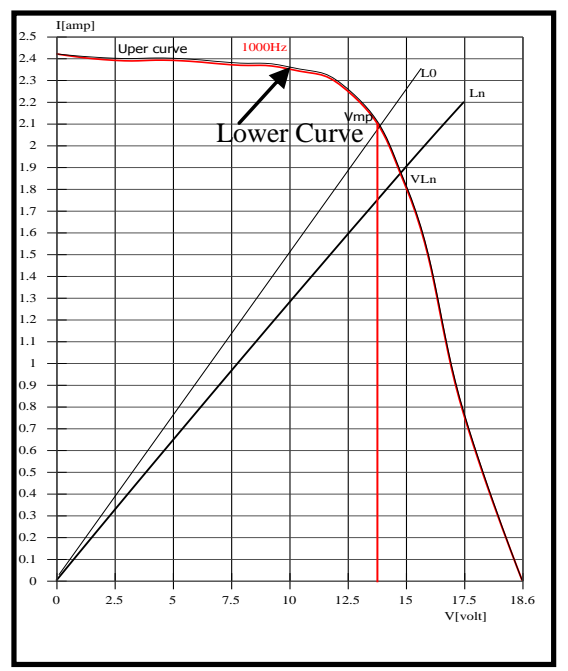

Fig. 8 : I-V Characteristics of SCA without Using DC chopper and the instant of Using it with Chopping Frequency $1000 \mathrm{~Hz}$. 


\section{RESULTS AND DISCUSSION}

Figure (9) shows the output voltage level of Schmitt circuit at this condition as recorded by the oscilloscope. As the load voltage is gradually increased than the UTP, Schmitt output changes its state automatically to negative level of - $\left(\mathrm{V}_{\mathrm{EE}}-1\right)$ as shown in Fig.(10) as recorded by the oscilloscope. So, (UTP) voltage is equal to the voltage drop on $R_{4}$.

$$
\mathrm{IR}_{7}=\text { UTP }
$$

$$
\mathrm{R}_{7}=\mathrm{UTP} / \mathrm{I}
$$

Current $\mathrm{I}$, is selected very large of the maximum biasing current of the IC.

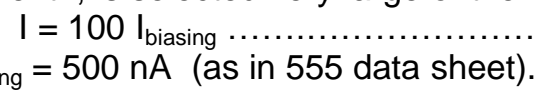

$\mathrm{R}_{7}=14.5 / \mathrm{I}=270 \mathrm{k} \Omega$

Where,

$$
\begin{aligned}
& \mathrm{R}_{6}=\frac{\mathrm{V}_{\mathrm{O}^{-}} \mathrm{UTP}}{\mathrm{I}} \\
& \mathrm{R}_{6}=10 \mathrm{k} \Omega
\end{aligned}
$$

The selection of diode depends on its reverse voltage, which must be greater than Schmitt output, and its forward current is I.

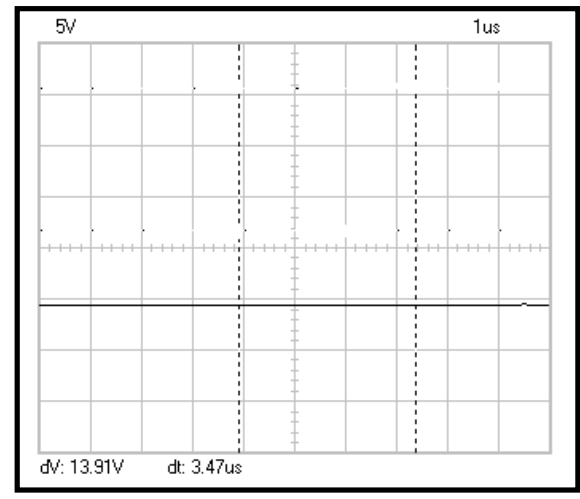

Fig.9 : Positive Voltage Level of Schmitt Output

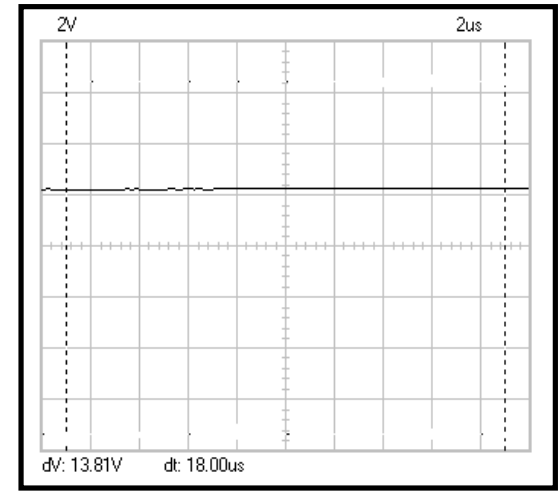

Fig. 10 : Negative Voltage level of Schmitt Output as its Input Goes up above UTP.

Figure (11) represents the inverter trigger pulses at $50 \mathrm{~Hz}$ for the stable and mono stable multi-vibrators. The figure shows that the phase shift between the upper and the lower pulses generated by the designed multivibrators. 


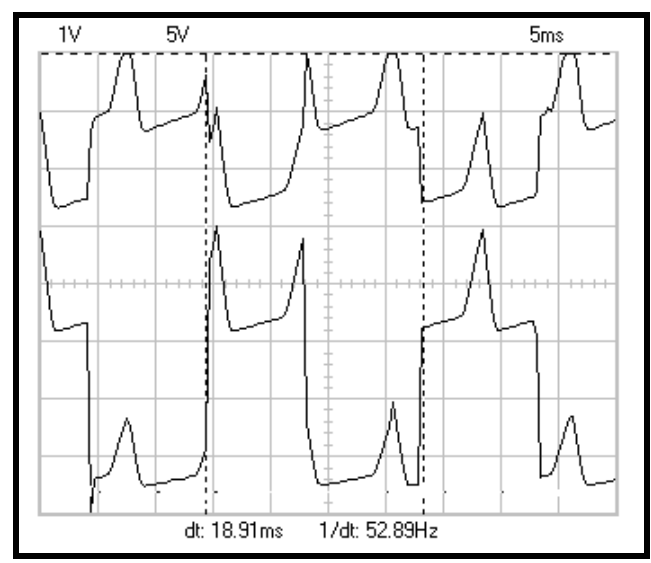

Fig.11 : Triggering pulses of Inverter Thyristors Corresponding to $50 \mathrm{~Hz}$.

The (DCC) triggering pulses at the optimum frequency $(1000 \mathrm{~Hz})$ and at that of the adjustable value, $900 \mathrm{~Hz}$ are shown in figures (12) and (13). The design of the inverter and (DCC) is out of this paper.

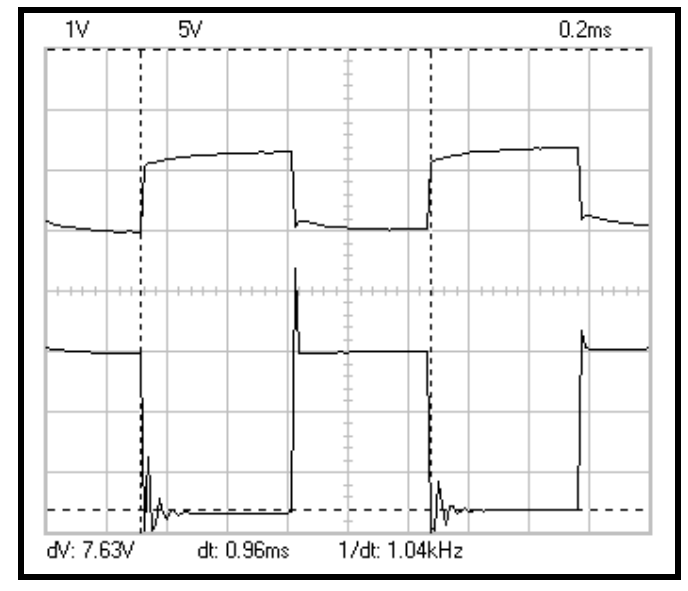

Fig.12 : Triggering Pulses of (DCC) Thyristors, Corresponding to the Optimum Frequency of $1000 \mathrm{~Hz}$. 


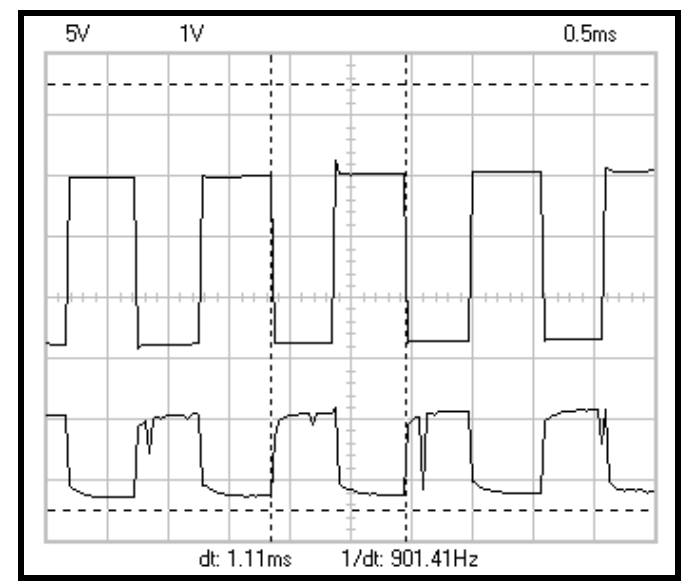

\section{Fig.13:Triggering Pulses of (DCC) Thyristors, Corresponding to Frequency $900 \mathrm{~Hz}$.}

\section{CONCLUSIONS}

Through this paper, proposed construction of the automatic voltage regulator device suitable for PVPS is illustrated. This voltage regulator mainly contains Schmitt circuit with lower trigger point is equal to zero. On the other hand, the upper trigger point of Schmitt circuit is designed greater than the voltage at maximum power point of the solar cells array. The device also contains switching transistor with its base biased from Schmitt circuit output. The proposed connection of the transistor switching circuit is in parallel with a stable multi-vibrator triggering circuit of the DCCC. In the normal condition of operation, the load voltage is equal to maximum power point voltage. At this circumstance Schmitt circuit output becomes positive and the transistor switches on. During the abnormal condition of load voltage through which the voltage diverts from that at MPP, the Schmitt output becomes negative and switches the transistor off. Chopping frequency of DCCC is altered to return back the load voltage to that at MPP. The automatic maximum power point tracker (MPPT) circuits coupled with solar cells array was designed procedures as well as its performance is investigated during operating DC irrigation pump at different levels of solar radiation. 


\section{REFERENCES}

Eskander S. S. "Regulation of load voltage supplied by solar cells array". The eighth international Middle East power systems conference, MEPCON 2001, December 29-31, 2011.

Patil. S. K., and. D.K. Mahadik 22012 " DESIGN OF MAXIMUM POWER POINT TRACKING (MPPT) BA SED PV CHARGER " IOSR Journal of Electronicsl and Communication Engineering (IOSR-JECE) ISSN: 2278-2834-, ISBN: 2278-8735, PP: 27-33 .

Rahmam,S, M. A. Khallat, and B. H. Chowdhury,"A discussion on the diversity in the applications of photovoltaic systems, IEEE Trans. Energy Conversion, vol. 3, pp. 738-746, Dec. 2008.

Salmah Z..A.K.Mulpur, and F, Dagher. Twostage electrical array reconfiguration controller for PV powered water pump, Proceding of 1998 annual meeting, American Solar Energy Society, pp. 399-404(20-24 June 1998).

Schaefer J.F. and L. 2005 "Some result regarding stability of photovoltatic maximum power point tracking DC- DC converters, Eighteenth IEEE Photovoltatic Specialists conference,pp 1484- 14882

Tse, K. K. , M. T. Ho, H. Chung, and S. Y. Hui, "A novel maximum power point tracker for PV panels using switching frequency modulation". IEEE Trans on Power Electronics, vol. 17, no. 6, November 2012.

[Yang, B. B, W. Li, Y. Zhao, and X. He, "Design and analysis of a grid connected photovoltaic power system", IEEE Transactions of Power Electronics, vol. 25, no. 4, pp. 992-1000, April 2012

Ziad M. Salameh, "Step Down Maximum Power Point Tracker for Photovoltatic Systems", Solar Energy, Vol. 46, 2010. 


\section{تصميم متتبع نقطة أقصي قرة متصل بمجموعة خلايا شمسية

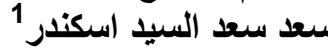 \\ حمدى محمد نور سلئ}

1 قمم بحوث القوى والطاقة - معهل بحوث الهندسة الزراعيةـ دقى- جيزة .

2 قسم هندسة القوى الكهربائية. كلية الهندسة - جامعة المنصورة .

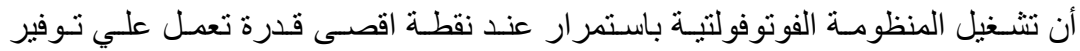

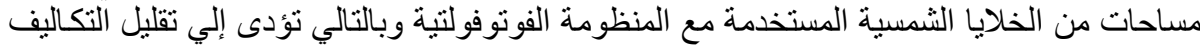

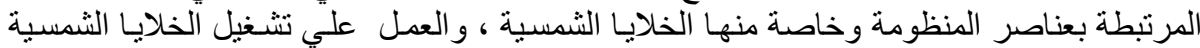

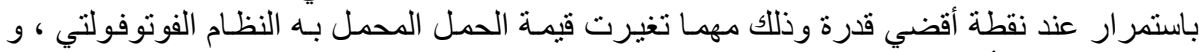

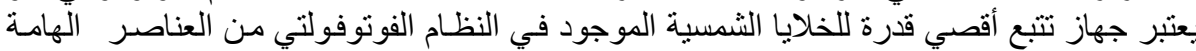

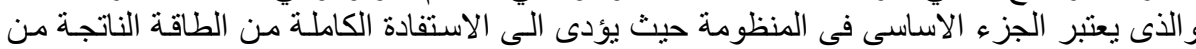

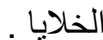

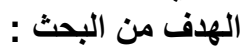

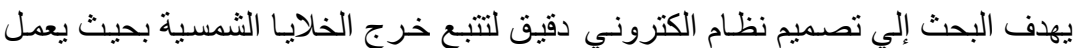

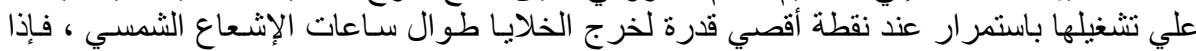

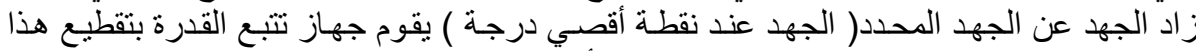

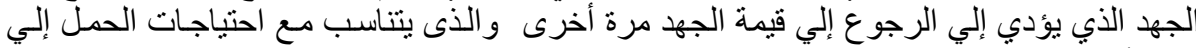

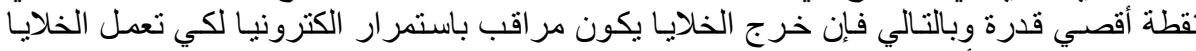

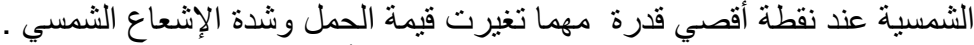

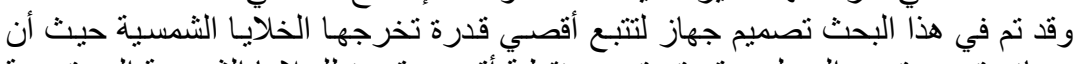

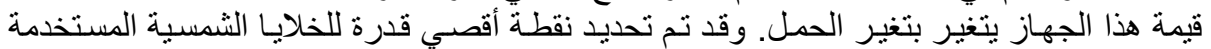

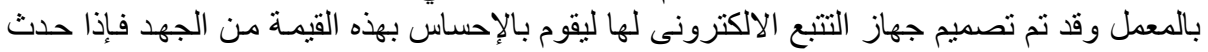

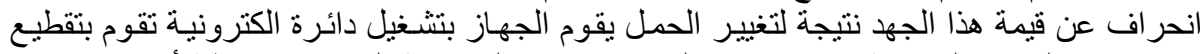

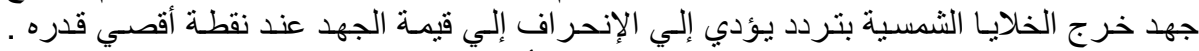

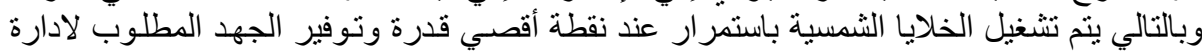

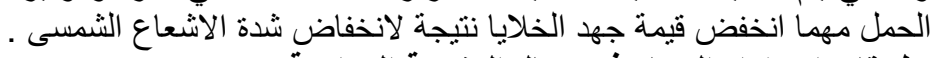

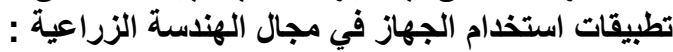

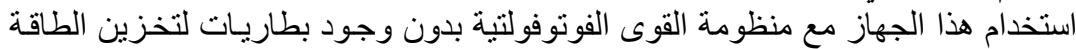

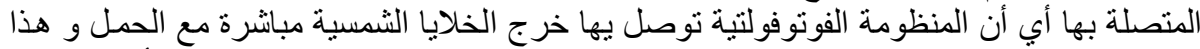

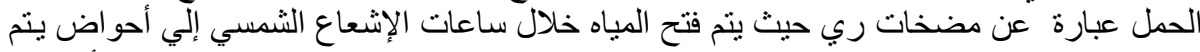

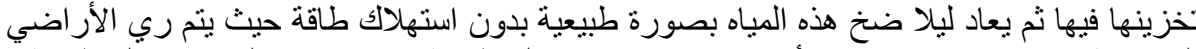

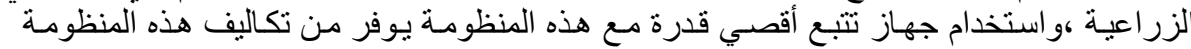

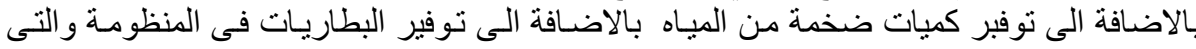
تصل قيمتها الى 40\% من تكاليف المنظومة . 